\title{
Roberto Saviano, czyli rzecz o kalaniu własnego gniazda i jego konsekwencjach
}

\section{Abstract \\ Roberto Saviano. A Few Words about Contaminating His Own Nest and Its Consequences}

Roberto Saviano is an Italian writer and investigative journalist who has been living under strict police protection for thirteen years. He wrote Gomorrah, a bestselling book, that drew the mafia's attention and resulted in a death sentence. Life in hiding is a price he pays for revealing the harsh truth about the activity of Neapolitan Camorra. The aim of this paper is to investigate what drives his uncompromising pursuit for truth, the strategies he uses to achieve this aim, and the response to his approach, coming from Italian politicians, intellectuals, ordinary people, and international general public.

Key words: camorra, Nestbeschmutzer, engagement, parrhesia

Słowa kluczowe: kamorra, Nestbeschmutzer, zaangażowanie, parezja 


\section{Pisarz celebryta}

Roberto Saviano jest dziś we Włoszech jedną z najbardziej rozpoznawalnych osobowości publicznych, kimś w rodzaju literacko-dziennikarskiego celebryty. Urodził się 40 lat temu w Neapolu, ale od najmłodszych lat mieszkał w Casal di Principe, niewielkim mieście oddalonym od stolicy Kampanii o niecałe $50 \mathrm{~km}$. Ponieważ właśnie tam przebywało wielu członków mafijnego klanu Casalesi, Casal di Principe po dziś dzień uważa się za twierdzę neapolitańskiej mafii zwanej kamorrą. W 2006 roku Roberto Saviano ukończył pracę nad swoją pierwszą i jak do tej pory najważniejszą powieścią non-fiction zatytułowaną Gomorra. Viaggio nell'impero economico e nel sogno di dominio della camorra (w polskim przekładzie autorstwa Aliny Pawłowskiej-Zampino Gomorra. Podróż po imperium kamorry). Jest to jedna z najpopularniejszych książek włoskich we Włoszech i na całym świecie. Sprzedała się w 10 milionach egzemplarzy i została przetłumaczona na ponad 50 języków (dane pochodzą od Wydawnictwa Sonia Draga, 2019). Sam Saviano stał się po jej wydaniu jedną z najbardziej uwielbianych i znienawidzonych osób we Włoszech i zyskał miano czołowego „kalacza” przede wszystkim Neapolu, ale i całych Włoch. W książce bardzo dokładnie opisał mechanizmy funkcjonowania kamorry, wymieniając przy tym nazwiska największych bossów mafijnych. Poruszył problem przestępczości wśród dzieci, nielegalnych wysypisk śmieci i zanieczyszczenia okolic Neapolu tonami toksycznych odpadów, zaznaczając, że to właśnie kamorra jest głównym graczem gospodarki odpadami, czyli tzw. biznesu śmieciowego. Poza tak oczywistymi działaniami mafii jak handel narkotykami czy przemyt broni, opisał również kontrolowane przez kamorrę zakłady produkcji tekstylnej, w których realizuje się projekty najważniejszych włoskich domów mody, a których pracownicy nie mają żadnych uprawnień - pracują na dwie zmiany, nie przysługują im jakiekolwiek świadczenia zdrowotne i nie posiadają prawa do urlopu. Saviano pokazał, jak funkcjonuje odbywający się w porcie neapolitańskim przemyt towarów, jak unika się tam kontroli i nielegalnie wypuszcza na rynek niezarejestrowane produkty. Przypomniał śmierć osób, które odważyły się sprzeciwić mafii i wyjawić prawdę na jej temat. Wskazał, jakie relacje istnieją pomiędzy gospodarką organizacji kryminalnych a legalną gospodarką państwową. Do wszystkich tych informacji autor docierał na różne sposoby. Już od samego początku miał jednak nieco ułatwione zadanie, ponieważ opisywane przez niego fakty i zdarzenia w dużej mierze dotyczyły obszaru, na którym się wychował i gdzie mógł im się przyglądać od dziecka. Aby dotrzeć do bardziej szczegółowych informacji, Saviano przebywał jak najbliżej działań kamorry - pracował w porcie neapolitańskim, był asystentem fotografa pracującego przy rodzinnych spotkaniach bossów kamorry, uczestniczył w procesach sądowych.

110

Fabrica Litterarum Polono-Italica | 2020, nr 1 (2) 
Gomorra... nie od razu cieszyła się tak ogromną popularnością. Przy pierwszym wydaniu, w marcu 2006 roku, została opublikowana tylko w pięciu tysiącach egzemplarzy i choć krytyka doceniła ją od samego początku, książka nie przyciągnęła zbyt licznej rzeszy czytelników. Sytuacja bardzo gwałtownie zmieniła się we wrześniu tego samego roku, kiedy na głównym placu Casal di Principe Saviano wykrzyczał nazwiska przebywających jeszcze wówczas na wolności bossów klanu Casalesi, zwracając się do nich słowami: „To nie jest wasza ziemia. Nic tutaj nie znaczycie. Wynoście się stąd!” (Monina 2013: 48). Po tym policzku wymierzonym klanowi, pisarz zaczął dostawać pierwsze listy z pogróżkami i głuche telefony. Ponieważ sytuacja wyglądała coraz groźniej, w październiku została mu przydzielona eskorta karabinierów. O autorze zrobiło się głośno, a jego książka zaczęła się sprzedawać w zawrotnym tempie. W tym czasie schwytany został jeden z członków klanu Casalesi, który zdradził policji, że na pisarza czeka już „drewniany płaszcz”, czyli wydano na niego mafijny wyrok śmierci. Wobec takiej zapowiedzi jego ochrona została wówczas wzmocniona i w takiej formie trwa do dzisiaj. Pierwsze lata po wydaniu książki, choć niezwykle trudne z perspektywy prywatnej, okazały się bardzo owocne dla literackiej kariery Saviana. Gomorrę... przez rok grano na deskach włoskich teatrów; na podstawie książki powstał wyreżyserowany przez Mattea Garrone i nagrodzony w Cannes film Gomorra; od 2014 roku możemy zaś oglądać serial pod tym samym tytułem. W 2008 roku Saviano usłyszał wiele głosów solidarności ze strony swoich czytelników. Wsparło go również kilku noblistów oraz słynnych ludzi pióra i polityki (m.in. Günter Grass, Dario Fo, Rita Levi Montalcini, Desmond Tutu, Orhan Pamuk, Michaił Gorbaczow, Claudio Magris, Jonathan Franzen, Peter Schneider, Josè Saramago, Lech Wałęsa, Wisława Szymborska, Chuck Palahniuk, Umberto Eco, Javier Marias, Martin Amis, Betty Williams), którzy apelowali o jeszcze większe wzmocnienie jego ochrony. Wraz z Salmanem Rushdiem został zaproszony do wygłoszenia mowy w Akademii Szwedzkiej. Całe to pasmo sukcesów, a także sympatia i solidarność ze strony części społeczeństwa i światowego środowiska literackiego są niewątpliwie jasną stroną następstw wyborów pisarza. Niestety, istnieje również ciemna ich strona: życie w odosobnieniu, samotność, wykluczenie, powszechna nienawiść i wiele społecznych oskarżeń. Znaczna część zawartych w niniejszym artykule rozważań dotyczy właśnie tej drugiej, mrocznej strony kariery pisarza. W tekście przyglądam się negatywnym reakcjom części włoskiego społeczeństwa na twórczość autora Gomorry..., wymieniam wysuwane przeciwko niemu zarzuty i zastanawiam się, dlaczego, pomimo tak wielu niedogodności, Saviano wciąż pisze. Aby odpowiedzieć na postawione pytanie, zwracam uwagę na takie wymiary jego pisarstwa jak zaangażowanie i strategie angażujące, transmedialne realizacje Gomorry..., parezjastyczne dążenie do odsłaniania i rozprzestrzeniania prawdy oraz niemalże misyjna potrzeba poszerzania świadomości społecznej. W artykule odnoszę się do myśli dwóch francuskich filozofów - opisuję Saviana jako Sartre'owskiego

111

Fabrica Litterarum Polono-Italica | 2020, nr 1 (2) 
pisarza zaangażowanego i Foucaultowskiego parezjastę. Ostatecznie, wykorzystując kategorie rozliczenia i obrachunku, zastanawiam się, czy włoskiemu pisarzowi udało się osiągnąć od początku zakładane cele.

\section{Odosobnienie i życie pod eskortą}

Na pierwszy rzut oka najdotkliwszą konsekwencją wyborów Saviana wydawać się może życie z wyrokiem śmierci, stałe przebywanie w ukryciu i niemal całkowita utrata wolności. Codzienność pisarza rzeczywiście nie jest prosta: zawsze otacza go kilku karabinierów, autor nieustannie zmienia miejsce zamieszkania, przemieszcza się w opancerzonych samochodach, ma bardzo ograniczone kontakty z ludźmi (Saviano 2010). Zapytany o strach przed śmiercią, odpowiada, że bardziej od niej przeraża go wizja, według której być może już zawsze będzie musiał żyć w ten sposób. W przytoczonym przez Giuseppe D’Avanzo wywiadzie dla „La Repubblica” wyznaje:

Chcę mieć dom, chcę się zakochać, wypić piwo w miejscu publicznym, iść do księgarni i wybrać sobie książkę, czytając, co jest na odwrocie okładki. Chcę spacerować, opalać się, chodzić w deszczu, spotykać się bez obaw z moją matką, nie wywołując strachu i u niej. Chcę mieć wokół siebie przyjaciół, móc się śmiać i nie musieć mówić o sobie, zawsze tylko o sobie, jakbym był śmiertelnie chory, a oni mieli obowiązek składania mi nudnych, ale nieuniknionych wizyt (za: D’Avanzo 2008; tłum. - W.K.).

Tak mówił dwanaście lat temu, zaznaczając później, że mimo wszystko nie żałuje swojej decyzji i gdyby mógł cofnąć czas, podjąłby taką samą raz jeszcze. Dziś nie jest już tego tak pewny. Z żalem przyznaje, że nigdy nie wybaczy sobie jednego: faktu, iż odebrał część wolności nie tylko sobie, ale i swoim najbliższym.

Zdarza się, że czytelnicy nie rozumieją, dlaczego pisarz aż tak rozgniewał bossów kamorry. Nie wyjawił przecież sekretów, o których absolutnie nikt nie wiedział. To prawda, ale choć już wcześniej pisano o mafii neapolitańskiej, Saviano jako pierwszy dotarł do tak ogromnej rzeszy odbiorców, skierował światło reflektorów na sprawy, o których jeśli nawet wcześniej rozmawiano, to robiono to szeptem, w kuluarach. Pokazał, że przestępstwa kamorry dotyczą nie tylko małej grupy polityków czy organizacji antymafijnych, ale właściwie wszystkich Włochów, którzy nawet nie wiedzą, jak daleko i na jak wiele obszarów ich życia rozciągają się macki neapolitańskich klanów oraz że oni sami są częścią tego mechanizmu, a kiedy o nim milczą, wyrażają bezgłośne przyzwolenie, stają się współwinni.

112

Fabrica Litterarum Polono-Italica | 2020, nr 1 (2) 
Okazuje się, że tak wielki rozgłos rozgniewał nie tylko mafię, ale też sporą część włoskiego społeczeństwa, która oskarżyła Saviana o zdradę i zniesławienie przede wszystkim Neapolu i jego okolic, ale również całego kraju i wszystkich mieszkańców. Nie codzienność pod okiem karabinierów i nawet nie ciągły strach o życie najbliższych, ale właśnie dyskredytacja ze strony włoskiego społeczeństwa stała się dla Saviana najboleśniejszą i najtrudniejszą formą izolacji. Podczas mowy wygłoszonej w Akademii Szwedzkiej autor Gomorry... mówił:

Mafia może wydać na ciebie wyrok, ale i tak najbardziej ranią cię oskarżenia społeczeństwa. Ludzie mówią, że gonisz za sukcesem, że wszystko, co zrobiłeś, zrobiłeś po to, aby cię zauważono. I że rujnujesz kraj. Zabolało mnie to ostatnie stwierdzenie. Ponieważ myślę, że opowiadać znaczy stawiać opór (Monina 2013: 95).

\section{Społeczne odrzucenie i techniki oczerniania}

Nagła popularność Casal di Principe wcale nie ucieszyła jego mieszkańców. Kiedy po roku od wydania Gomorry... Saviano odwiedził rodzinne miasto, część dawnych sąsiadów dosłownie wygwizdała pisarza. Szczególnie niezadowoleni byli też neapolitańczycy, zdaniem których Saviano w sposób cyniczny oczernił ich miasto oraz ich samych. Nazywali go: diffamatore („kalacz”, „zniesławiacz”), traditore („zdrajca”), sputtanapoli („ktoś, kto bruka Neapol”), a nawet munnezza (wł: monnezza: „śmieć”). W 2017 roku na ulicach Neapolu przeprowadzono ankietę, podczas której mieszkańcy miasta zostali poproszeni o wyrażenie opinii na temat Saviana. Poza nielicznymi pozytywnymi komentarzami większość osób wypowiedziała się o nim bardzo negatywnie, oskarżyła go o sprzedajność, oportunizm i podważyła wiarygodność jego słów, mówiąc na przykład: „łatwo jest być takimi Savianami i stać sobie w świetle reflektorów” albo: „Saviano kłamie. W Neapolu nie ma żadnej mafii” czy też: „Moim zdaniem Saviano jest kimś, kto zarobił pieniądze, choć wcale na nie nie zasłużył, ponieważ wykorzystał swoją wiedzę tylko po to, aby wylać na Neapol pomyje". Jedna z rozmówczyń stwierdziła, że, w jej przekonaniu, Saviano jest oszustem, który od początku współpracuje z kamorrą, ponieważ w przeciwnym razie mafia już dawno by go zabiła. Jak widać, temperatura oskarżeń wysuwanych przeciwko autorowi wcale nie spada. Dzieje się tak dlatego, że Saviano nie daje za wygraną - wciąż porusza niewygodne tematy (mafia, imigracja), publikuje we włoskiej i zagranicznej prasie, od lat występuje w telewizji, żywo wypowiada się na portalach internetowych. W ostatnich latach wydał dwie kolejne książki (Chłopcy

113

Fabrica Litterarum Polono-Italica | 2020, nr 1 (2) 
z paranzy i Drapieżny pocałunek), w których opowiada o dziecięcych grupach przestępczych wykorzystywanych przez kamorrę. Po publikacji tej pierwszej, na moście w Sanità, czyli opisanej przez niego dzielnicy Neapolu, pojawił się wielki transparent z napisem: „Saviano: Kamorra i renegaci nie mają narodowości = Neapol potrzebuje miłości, nie błota”. Autor skomentował to tylko jednym zdaniem: „Nieodróżnianie opisu rzeczywistości od błota jest czymś okropnym" (ten i wszystkie powyższe cytaty tego podrozdziału pochodzą z nagrania: Youtube, In giro per Napoli per capire cosa pensa la città di Roberto Saviano, e se le sue storie sono vere).

Poza sprzedajnością i oportunizmem pisarzowi wielokrotnie zarzucano też brak wiarygodności. Kilka lat temu rozgorzała dyskusja, podczas której zastanawiano się, czy autorowi rzeczywiście grozi jakiekolwiek niebezpieczeństwo i czy potrzebna jest mu ochrona. Pasquale Squitieri, zmarły niedawno reżyser filmowy (i również neapolitańczyk), wyznał, że nie zdziwiłby się, gdyby rzekome mafijne pogróżki kierowane pod adresem pisarza nigdy nie istniały i gdyby Saviano sam je sobie wymyślił. Stwierdził jednocześnie, że skoro pisarz jest w aż tak trudnym położeniu, nie powinien opuszczać kryjówki, nadużywać uprzejmości karabinierów i podczas swych publicznych wystąpień narażać innych osób (Cepollaro 2016).

Dosyć często włoscy internauci i półprofesjonalni publicyści określają Saviana modnym ostatnio słowem „buonista”, definiującym osobę, która pod przykrywką dobra i zaangażowania tak naprawdę działa na własną korzyść, zazwyczaj w celu zdobycia pieniędzy, sławy i wykreowania dobrego wizerunku.

W tej sprawnie działającej machinie oczerniania pisarza swoje miejsce odnalazło także trzech, szczególnie wrogo nastawionych do niego polityków. Po wielkim sukcesie serialu i głośnej we Włoszech promocji książki La paranza dei bambini znany z antypatii do Saviana burmistrz Neapolu Luigi de Magistris napisał na swoim facebookowym profilu:

Drogi Saviano, za każdym razem, kiedy w Neapolu dochodzi do jakiegoś przestępstwa, bardziej lub mniej poważnego, od razu pojawia się twoje słowo, jakaś twoja myśl, jakaś inwektywa [...]. Wydaje się, jakbyś tylko czekał na przestępstwa, żeby móc potwierdzić swoje prawdy. Im więcej się strzela, tym większe są twoje dokonania [...]. Czyż nie jest tak, że budujesz swoje imperium kosztem Neapolu i neapolitańczyków? Wzbogacasz się na naszym wysiłku, naszych cierpieniach i naszych walkach. Jakie to smutne [...]. Chcę wciąż myśleć, że tak naprawdę wcale nie znasz Neapolu, a może nigdy go nie znałeś. Dla mnie to oczywiste, że go nie kochasz. Oceniasz go, pogardzasz nim, ale tak naprawdę nic o nim nie wiesz. Prawdziwy i uczciwy intelektualista, zanim zacznie mówić i pisać, poznaje, próbuje zrozumieć, analizuje. Drogi Saviano, przestań wreszcie spekulować naszym kosztem. Ubrudź sobie ręce prawdziwą pracą. Przyjedź tu, wejdź pomiędzy nas, pomiędzy neapolitańczyków, którzy

114

Fabrica Litterarum Polono-Italica | 2020, nr 1 (2) 
każdego dnia walczą o zmianę, którzy cierpią, żyją w zagrożeniu, ale mają nadzieję i wciąż potrafią się uśmiechać (de Magistris 2019; tłum. - W.K.).

Wszystkie powyższe zarzuty Saviano słyszał już wielokrotnie. A jednak wypowiedź burmistrza robi wrażenie wyjątkowo bezczelnej i wyraźnie przekracza granice dobrego smaku. Proponowanie wejścia pomiędzy neapolitańczyków osobie, która w konsekwencji własnej aktywności od dekady ukrywa się przed jednym z najgroźniejszych klanów na świecie i przebywając w mieście swojego pochodzenia, za każdym razem spędza noc na komisariacie policji oraz przy wzmożonej ochronie, jest nie tylko absurdalne, ale przede wszystkim służy umniejszeniu, strywializowaniu i zdeprecjonowaniu jej działań. Najwyraźniej zdaniem de Magistrisa, który zaprasza Saviana do „ubrudzenia sobie rąk prawdziwą pracą”, intensywna działalność literacka i publicystyczna, uparte dociekanie prawdy, a także regularne komentowanie aktualnej sytuacji politycznej i społecznej w kraju oraz na świecie „prawdziwą pracą" nie jest. Choć wciąż absurdalna, wrogość polityka wobec autora Gomorry... staje się nieco bardziej zrozumiała, kiedy uświadomimy sobie, że pisarz wielokrotnie krytycznie odnosił się do działań burmistrza. W 2016 roku pisał na przykład:

Neapol jest pod obstrzałem [...]. A jednak największą siłą de Magistrisa była w tych latach jego przebiegłość: pozwolił uwierzyć, że piękno Neapolu jest właśnie jego sprawą, przemoc zaś nie, przestępczość nie, utrzymanie porządku nie. Pozwolił wierzyć, że wszystko, co czyni życie neapolitańczyków niemożliwym, jest niezależne od niego, wykracza poza jego kompetencje (Saviano 2019d, tłum. - W.K.).

Poza de Magistrisem, za Savianem nie przepada też Silvio Berlusconi, trzykrotny premier Włoch, lider partii Forza Italia i właściciel telewizyjnej sieci Mediaset, który w publicznej wypowiedzi obiecał udusić wszystkich włoskich twórców poruszających temat mafii. Zdaniem premiera reklamują oni organizacje przestępcze i przyczyniają się do pogorszenia wizerunku Włoch na arenie międzynarodowej. To oni odpowiedzialni są więc za fakt, że za granicą Włochy kojarzą się przede wszystkim z mafią. A przecież mafia ta, choć najbardziej znana, wcale nie jest ani największa, ani najgroźniejsza na świecie (Berlusconi 2010).

Na wszystkie tego rodzaju zarzuty Saviano odpowiada zawsze bardzo podobnie. W Chodź ze mnq, czyli zbiorze krótkich tekstów spisanych na podstawie programów emitowanych na antenie Rai 3 autor wyznaje: „Najbardziej mnie boli, że jestem oskarżany o oczernianie mojego kraju tylko dlatego, że o tym mówię. Tymczasem kto o tych wszystkich sprawach wspomina, nie oczernia kraju, lecz go broni" (Saviano 2014: 141).

115

Fabrica Litterarum Polono-Italica | 2020, nr 1 (2) 
Okazuje się, że zarzuty ze strony de Magistrisa i Berlusconiego były tylko preludium do ostrego konfliktu Saviana z innym politykiem - Matteem Salvinim, liderem eurosceptycznej partii Liga Północna (Lega Nord), a od 2018 wicepremierem i ministrem spraw wewnętrznych. Mężczyźni od wielu lat zawzięcie się ze sobą spierają. Saviano ostro krytykuje politykę migracyjną Salviniego, jego nieprzejrzyste transakcje finansowe (np. związane z wydatkami na kampanię wyborczą Ligi), brak wyraźnego sprzeciwu wobec mafii (kontakty z członkami związanej z 'ndrànghetą rodziny Pesce), ukrywanie powiązań pomiędzy Ligą Północną a 'ndrànghetą, propagowanie kłamstw, korzystanie z mafijnych metod zastraszania itd. W czerwcu 2018 roku, w jednym z programów telewizyjnych Matteo Salvini podał w wątpliwość konieczność dalszego finansowania eskorty Saviana i obiecał, że odpowiednie instytucje sprawdzą, czy autorowi Gomorry... wciąż grozi jakieś niebezpieczeństwo oraz czy pieniądze Włochów wydawane są w odpowiedni sposób. Polityk już wcześniej zapowiedział, że jeśli jego partia dojdzie do władzy, on sam zatroszczy się o to, aby pisarz został pozbawiony eskorty. W odpowiedzi na słowa Salviniego, na swoim profilu facebookowym Saviano zamieścił krótkie nagranie, w którym bezpośrednio zwrócił się do ministra słowami:

Czy według ciebie, Salvini, jestem szczęśliwy, że żyję tak od jedenastu lat? Od ponad jedenastu lat? Mam eskortę, odkąd skończyłem 26. rok życia. Przez cały ten czas byłem pod ogromną presją ze strony Casalesich, pod presją meksykańskich handlarzy narkotyków. Bardziej boję się tak żyć, niż umrzeć. Czy ty naprawdę myślisz, że mógłbym się ciebie bać, bufonie? (Saviano 2019c; tłum. - W.K.).

Na fali ostrej wymiany zdań Saviano nazwał polityka „il ministro della malavita”, czyli ministrem świata przestępczego. Niedługo później wicepremier skierował sprawę do sądu, wnosząc przeciwko pisarzowi akt oskarżenia, ponieważ, jak wyznał, nie pozwoli na to, aby ktoś zarzucał mu kontakty z mafią, z którą od tak wielu lat zawzięcie walczy.

Spór na linii Saviano-Salvini wywołał zażartą dyskusję pomiędzy zwolennikami jednej i drugiej strony. Po stronie Saviana stanął prezes stacji La7 Andrea Salerno, który zauważył, że autor Gomorry... z całą pewnością wolałby żyć bez eskorty, ale dziś nie zależy to jeszcze od niego, ponieważ wciąż grozi mu niebezpieczeństwo. W sprawę zaangażował się też Salman Rushdie, który wyznał: „Mam nadzieję, że władze włoskie będą dalej zapewniać ochronę człowiekowi, którego ja i wiele innych osób uważamy za doskonałego pisarza i bohatera wolności wypowiedzi" ([b.a.] 2018). Bardzo głośno wybrzmiał też głos internautów. Portale społecznościowe zalała fala hasztagów o treści \#SavianoNonSiTocca (\#NieDotykaćSaviana) i \#loStoConRobertoSaviano (\#JestemZRobertemSavianem). Z drugiej strony na Facebooku

116

Fabrica Litterarum Polono-Italica | 2020, nr 1 (2) 
pojawiły się fanpage „lo sto con Matteo Salvini” („Jestem z Mateem Salvinim”) oraz „L'esercito di Matteo Salvini: difendiamo il nostro ministro degli interni” („Wojsko Mattea Salviniego: bronimy naszego ministra spraw wewnętrznych"). Internauci zajęli już swoje stanowiska, ale proces sądowy pomiędzy Savianem a Salvinim wciąż czeka na ostateczne rozstrzygnięcie.

\section{Sartre'owski pisarz zaangażowany i Foucaultowski parezjasta}

Skoro praca Saviana pociąga za sobą tak wiele przykrych konsekwencji i wiąże się z realnym zagrożeniem jego życia, dlaczego autor nie przestaje pisać? Dlaczego nie zamilknie lub przynajmniej nie złagodzi swojego tonu i nie zacznie poruszać kwestii mniej kontrowersyjnych niż przestępczość mafijna czy migracje (to ostatnio główny temat jego twórczości)? Spójrzmy na fragment wypowiedzi pisarza zamieszczonej w zbiorze esejów pod tytułem Piękno i piekło:

Sądzę, że duża odpowiedzialność spoczywa na intelektualistach. Wrażenie nieograniczonego dostępu do wartościowych informacji, jakie mogą mieć obywatele zachodniego świata, kiedy czytają gazety, wchodzą do księgarń czy oglądają filmy, jest mylne. Rola pisarza polega właśnie na tym - powinien pokazać, że wiele spraw pozostaje przemilczanych albo przedstawia się je w sposób tendencyjny, i to nie tylko dlatego, że ktoś nie dopuszcza do rozpowszechniania rzetelnie opisanych historii, ale dlatego, że odbiorcom trudno do nich dotrzeć i właściwie je odebrać (Saviano 2010: 185).

Zaangażowanie jest, według Saviana, obowiązkiem intelektualisty, nie wyborem czy pewną możliwością, lecz odpowiedzialnością spoczywającą na ludziach zawodowo zajmujących się literaturą, historią, filozofią czy sztuką. Skoro potrafią oni selekcjonować informacje, odczytywać je i wyciągać z nich wnioski, muszą to robić „na głos", ponieważ tylko w ten sposób są w stanie uświadamiać osoby, które na co dzień gubią się w natłoku przekazywanych im treści. Zdaniem pisarza bardzo przydatnym i skutecznym narzędziem służącym do wyjawiania i objaśniania prawdy oraz angażowania w nią czytelników jest literatura. Pisał:

[...] literatura ma moc odsłaniania mechanizmów, ukazywania przestępstw w sposób nietypowy i niestereotypowy. [...] Literatura trafia do serc, do żołądków i do głów czytelników. [...] Ktoś kiedyś stwierdził, że po Primo Levim i po jego książce Czy to jest człowiek nikt już nie może powiedzieć, że nie był w Auschwitz. Nie że nie słyszał o Auschwitz, ale że w nim nie był. Właśnie ta

117

Fabrica Litterarum Polono-Italica | 2020, nr 1 (2) 
zdolność literatury przeraża siły przestępcze i inne. Fakt, że opisane problemy czytelnicy odczuwają jako własne (Saviano 2010: 157).

W Gomorze... Saviano ukazuje prawdę tak, by czytelnicy zaczęli ją traktować jako własną sprawę, za którą od momentu jej poznania stali się współodpowiedzialni. Wiedząc, że typowo dziennikarskie czy typowo naukowe teksty na temat kamorry nie przyciągają wystarczającej liczby odbiorców, autor postanowił napisać książkę formalnie zróżnicowaną, wciągającą i w miarę możliwości prostą w odbiorze. A przede wszystkim zrozumiałą i angażującą. Debiutanckie dzieło Saviana jest utworem hybrydycznym, gatunkowo nieczystym, bo mieszczącym w sobie cechy m.in. powieści, dziennika, reportażu, raportu dziennikarskiego czy autobiografii. W tej złożonej opowieści na temat faktycznych wydarzeń, autentycznych zbrodni i prawdziwych ludzi, nieustannie przeplatają się ze sobą elementy fiction i non-fiction. Należy jednak pamiętać, że fikcjonalność Gomorry... nie ma nic wspólnego ze zmyśleniem w kontekście faktograficznym. Pojawia się raczej w warstwie dyskursywnej, na poziomie struktury i montażu, pod postacią rozmaitych zabiegów z repertuaru literatury pięknej, umożliwiających umiejętne wypełnienie luk pomiędzy faktami a dokumentami, tj. w formie różnych strategii narracyjnych, strategii portretowania postaci czy licznych zabiegów retorycznych (metafory, porównania, hiperbole, kontrasty). Jak zauważył Wu Ming 1, właśnie owa „literackość” tekstu jest jedną z największych jego wartości, ponieważ „gdyby ta książka była tylko reportażem, nie pozwoliłaby nam zrozumieć tak wielu rzeczy na temat Systemu, nie pokazałaby nam, w jakim sensie kamorra dotyczy nas wszystkich [...], nie wyczuliłaby nas na to, jak pilnie należy przeanalizować dynamikę rynku i konsumpcji” (Wu Ming 1 2008, tłum. - W.K.).

Mówiąc o gatunkowych zawiłościach swej książki, Saviano wielokrotnie wspominał o inspiracji twórczością autorów New Journalism, a przede wszystkim niefikcjonalną powieścią Z zimna krwiq Trumana Capote’a. Spójrzmy:

Nie chciałem napisać klasycznego eseju ani zwyczajnego utworu fiction, [...] zainspirowałem się więc gatunkiem nonfiction novel Trumana Capote. Wykorzystałem swobodę i dowolność powieści i skrzyżowałem je z rygorem statystyk, archiwów, badań socjologicznych. W takiej perspektywie literatura przestaje być ucieczką od rzeczywistości, którą często bywała dla autorów z południowych Włoch, a staje się narzędziem służącym do opisu świata, który wszyscy mają przed oczami, choć pozornie wydaje się on nieuchwytny (Gambaro 2007).

Pomimo wielu podobieństw, nonfiction novel Saviana i Capote’a różni co najmniej jeden istotny element - narrator. O ile w Z zimnq krwiq jest on właściwie przezroczysty, w Gomorze... ustawia się w samym centrum świata przedstawionego,

118

Fabrica Litterarum Polono-Italica | 2020, nr 1 (2) 
jest mocno spersonalizowany oraz emocjonalnie $\mathrm{i}$ intelektualnie zaangażowany w wydarzenia, o których opowiada. A jednak jego świadectwo skupia się przede wszystkim na losie innych osób, bliżej niż on powiązanych z kamorrą. Kiedy Roberto-narrator użycza im swojego głosu, sam chowa się za postacią, której dotyczy opowiadana akurat historia. Czytelnik ma wówczas wrażenie, że zostaje z bohaterem sam na sam, że to przed jego, nie Roberta, oczami rozgrywa się cała scena. Zostaje jakby wrzucony w sam środek dziania się. Spójrzmy, jak o tej narracji pisał cytowany już tu wcześniej Wu Ming 1:

Oto jesteśmy, śledzimy jakąś postać z pewnej odległości, z ukrycia. W którymś momencie nadchodzi „kiedy go spotkałem, powiedział mi” (lub coś w tym rodzaju). I nagle gwałtowny zoom na postać. Ta ostatnia zwraca się do Saviana, a dzięki „ja mówiącemu" to my jesteśmy Savianem. To trochę tak, jak kiedy aktor rzuca swoje spojrzenie w obiektyw i patrzy nam prosto w oczy. Zoom + spojrzenie w obiektyw: ta narracyjna sztuczka ma niewiarygodne oddziaływanie. Pomyślmy tylko o trasie Cira, sottomarino, który roznosił „wypłatę" rodzinom skazanych (s. 159-161). Saviano zdradza nam, że go poznał, ale mówi to en passant. Niewiele sobie z tego robimy, ponieważ poznaliśmy już Cira, idziemy za nim, kiedy przemierza wąskie uliczki, wspina się po schodach, pokonuje klatki schodowe, wysłuchuje narzekań. Uczestniczymy w jego wyprawie, jesteśmy tuż obok niego, plastikowe siatki wypełnione żywnością ocierają się o nasze nogi, towarzyszymy mu również teraz, kiedy wyprawa już się skończyła. Jesteśmy oczarowani... Potem nadchodzą cztery słowa („kiedy z nim rozmawiałem") i odkrywamy, że Saviano idzie z nami. Albo lepiej, że to my nim jesteśmy (Wu Ming 1 2008, tłum. - W.K.).

Taki sposób snucia opowieści jest tylko jedną z licznych strategii prowadzących do jak największego zaangażowania czytelnika w historię. Choć już sama narracja pierwszoosobowa niewątpliwie skraca dystans pomiędzy czytelnikiem a "ja” mówiącym, Saviano poszedł w Gomorze... o krok dalej. Wykorzystał narrację drugoosobową (diadyczną), przez co wciągnął czytelnika w bieg zdarzeń w sposób jeszcze bardziej sugestywny, jeszcze mocniej zatarł granice pomiędzy światem tekstowym i pozatekstowym. Spójrzmy:

Kiedy widzisz tyle krwi, odruchowo dotykasz się, żeby sprawdzić, czy nie jest twoja, ogarnia cię psychotyczny lęk, że zraniłeś się, nie zauważywszy tego nawet, sprawdzasz, czy na twoim ciele nie ma krwawiących ran [...] czujesz się pusty w środku, jakbyś naprawdę miał krwotok: nogi uginają się pod tobą, w ustach wysycha ślina, dłonie wydają się rozpuszczać w tej gęstej cieczy, pragniesz, żeby ktoś spojrzał na twoje oczy i sprawdził, czy nie dostałeś anemii (Saviano 2008a: 134).

119

Fabrica Litterarum Polono-Italica | 2020, nr 1 (2) 
Tak zaangażowany na poziomie cielesnym i emocjonalnym czytelnik przestaje być zwykłym adresatem i w pewnym sensie staje się kolejną postacią, niemalże pełnoprawnym uczestnikiem zdarzeń. Im głębiej się w nie zanurzy, im mocniej podda się złudzeniu przebywania w krwawej rzeczywistości kamorry, tym większą być może poczuje potrzebę poszerzenia swojej wiedzy na jej temat oraz niezgody na takie jej funkcjonowanie.

Zdaniem Saviana tylko świadomość i rozumienie skomplikowanych mechanizmów działań mafijnych oraz własnej w nich roli może dawać nadzieję na naprawę rzeczywistości. Jedynie masowa świadomość i masowe zaangażowanie byłoby w stanie jeżeli nie rozsadzić, to przynajmniej bardzo dotkliwie poturbować system mafijny.

W tym kontekście trudno nie zauważyć spójności postawy Saviana z Sartre'owską koncepcją intelektualisty zaangażowanego. Sartre twierdził, że pisanie powinno być apelem do czytelnika, domaganiem się jego uwagi i uważności oraz prośbą o współpracę. Jego zdaniem pisarz musi wzbudzać w czytelnikach odpowiedzialność za to, co im zdradził, czyli „ma za zadanie uczynić tak, żeby każdy musiał znać świat i żeby nikt nie mógł uznać się za niewinnego” (Sartre 1968: 175). Na tytułowe pytanie przywołanego właśnie tekstu Czym jest literatura, Sartre odpowiadał, że zaangażowaniem społecznym. Odpowiedź Saviana brzmiałaby z pewnością bardzo podobnie. Pisarz odrzuca wysokoartystyczny wymiar literatury i nadaje jej znaczenie przede wszystkim utylitarne:

Ja nie chcę mieć nic wspólnego z [...] literaturą ulotnych myśli, z pięknymi historiami, w których nie ma krwi naszych czasów, które trzymają się z daleka od zgnilizny polityki i stęchlizny interesów. Istnieje taka literatura, która może mieć ogromną wartość i cieszyć się dużym powodzeniem. Ale ja nie mam z nią nic wspólnego (Saviano 2010: 125).

Zgodnie z myślą Sartre’a, Saviano jest jako intelektualista świadkiem epoki, uważnym obserwatorem rzeczywistości, który nie tylko dotrzymuje kroku własnym czasom, ale też zajmuje się tematami trudnymi i bolesnymi, przerywa milczenie, buntuje się przeciwko obojętności, odsłania tajemnice i demaskuje kłamstwa, a ostatnio bardzo zacięcie walczy z licznymi we włoskim życiu publicznym fake newsami'.

1 Na początku 2019 roku ukazała się jego nowa książka In mare non esistono taxi. Publikacja dotyczy tematyki migracyjnej. Podczas gdy Gomorra... i inne wypowiedzi pisarza na temat mafii miały być przede wszystkim głosem przeciwko milczeniu i obojętności, ten utwór autor określił jako świadectwo przeciwko kłamstwu i manipulacji. Saviano obnaża w nim pełną fałszu propagandę antyimigracyjną. Pokazuje, jak kłamstwa nagromadzone wokół migrantów prowokują irracjonalną nienawiść i nieuzasadniony lęk. Książka jest głosem sprzeciwu, świadectwem

120

Fabrica Litterarum Polono-Italica | 2020, nr 1 (2) 
Dziś Gomorra... jest już nie tylko książką, ale całą duża marką, brandem, rozbudowanym transmedialnym² ${ }^{2}$ projektem, obejmującym m.in. film, sztukę teatralną i czterosezonowy do tej pory serial, z którego wyrasta cały ogromny fandom (piosenki, krótkie filmiki, opowiadania fanfiction, gry, fotografie, parodie, gadżety fanowskie, powieści graficzne, kampanie itd.). Wszystkie wymienione dzieła są owocem twórczości wielu różnych autorów, ale sam Saviano miał bardzo duży wpływ na ich powstawanie. Współtworzył scenariusz zarówno do spektaklu teatralnego, filmu, jak i serialu. Od początku odgrywał istotną rolę w transmedialnych losach Gomorry..., tak jakby chciał, aby o książce nieustannie pamiętano i wciąż odczytywano ją na nowo. A jeśli nawet nie konkretnie tę, napisaną w 2006 roku książkę, to z całą pewnością zawarte w niej historie, analizy i obserwacje. Warto zauważyć, że transmedialny los Gomorry... bardzo wyraźnie przyczynił się do osiągnięcia od początku zakładanych przez Saviana celów ${ }^{3}$, a mianowicie poszerzenia społecznej świadomości na temat kamorry, zrozumiałego ukazania mechanizmów działań mafijnych, zaangażowania ludzi w tę tematykę i przede wszystkim dotarcia do jak największej rzeszy odbiorców.

Ten ostatni element wydaje się bardzo istotny w całej działalności twórczej Saviana. Jedną ze strategii jego zaangażowania i angażowania odbiorców jest metoda rozplenienia, rozsiania treści tak, aby trafiły one do możliwie szerokiej i zróżnicowanej grupy osób. Pisarz od lat pojawia się w bardzo wielu miejscach, gdzie konsekwentnie wypełnia swoją misję bezkompromisowego komentowania rzeczywistości. Można go spotkać podczas rozmaitych wydarzeń literackich i festiwali filmowych,

tego, co rzeczywiście spotyka uchodźców, kim naprawdę są ludzie uciekający do Europy, jakie towarzyszą im emocje i doświadczenia, a także w jaki sposób działają statki organizacji pozarządowych oraz dlaczego nazywanie ich „taxi del mare” (morskie taksówki) należy uznać za wyjątkowo bezczelne nadużycie.

2 Definiując pojęcie transmedialności i transmedialnych historii, warto odwołać się do słynnej książki Kultura konwergencji. Zderzenie starych i nowych mediów Henry’ego Jenkinsa (zob. Jenkins 2007). Według badacza historie transmedialne są wielowymiarowymi i wielowątkowymi opowieściami rozproszonymi po kilku różnych platformach. Tak oto rzecz opowiedziana w jednym medium zostaje rozwinięta, przetworzona lub dopowiedziana w innym medium. Wokół tekstu wyjściowego powstaje cała konstelacja utworów satelickich i choć można je odbierać pojedynczo, dopiero tropienie poszczególnych fragmentów pozwala na głębsze i pełniejsze poznanie rzeczywistości, którą opisują.

3 Pytanie tylko, czy w ostatnich etapach całego procesu (wielkiej fali popularności serialu i aktywności bardzo zaangażowanego fandomu serialowego) nie zapomniano o jednym z najważniejszych założeń początkowych pisarza - aby nie odrealniać i nie mitologizować obrazu rzeczywistości mafijnej, a pokazać ją z najgorszej, ale i najprawdziwszej strony. Wielu Włochów wyraża w tej kwestii spore zaniepokojenie, które sam autor ocenia jako bezpodstawne. Ponieważ transmedialna przygoda Gomorry... wciąż trwa i jeszcze nie wiadomo, jak się zakończy, na tym etapie najrozsądniej byłoby bacznie obserwować sytuację i wstrzymać się od ostatecznych ocen. Rozumiem jednak obawy Włochów.

121

Fabrica Litterarum Polono-Italica | 2020, nr 1 (2) 
nieustannie zabiera głos w telewizji i w prasie, prężnie działa w przestrzeni internetowej - na portalach społecznościowych i na kanale youtubowym Gomorra Channel, gdzie zamieszcza bardzo cenne materiały przede wszystkim o tematyce mafijnej, będące często rozwinięciem, wyjaśnieniem czy innym ujęciem tematyki zawartej w Gomorze..., a więc czymś w rodzaju kolejnego ogniwa transmedialnej przygody jego książki.

Saviano z całą pewnością nie należy do pisarzy, którzy po wydaniu książki odcinają się od jej komentowania i odmawiają interpretacji. Przeciwnie, zdaje się, że każdy nowy utwór traktuje jako pretekst do rozpoczęcia dyskusji oraz całej serii wypowiedzi w różnych miejscach, na różnych platformach i dla różnych odbiorców. Autor doskonale wie, że cele towarzyszące jego zaangażowaniu wymagają bardzo dużych zasięgów, dlatego tak istotny wydaje się komercyjny sukces jego twórczości. Od lat opracowywana przez niego mieszanka rozpoznawalności i autorytetu (przynajmniej wśród części czytelników) jest najwyraźniej przepisem na skuteczne budowanie wśród odbiorców najpierw zainteresowania, następnie coraz większej świadomości, a ostatecznie być może też niezgody na zastaną rzeczywistość i zaangażowania w zmianę.

Jako wzorcowy parezjasta Saviano dzieli się swoją wiedzą głośno, otwarcie, szczerze i bezpośrednio. Jest głęboko przekonany co do słuszności własnych działań, wytrwale przyjmuje ryzyko odsłaniania prawdy, nie ustępuje pod żadną presją i jak wiemy, za swoje zaangażowanie wciąż płaci bardzo wysoką cenę. Greckiemu zagadnieniu parezji bardzo wiele uwagi poświęcił Michel Foucault, który definiował ją w taki oto sposób:

To summarize the foregoing, parrhesia is a kind of verbal activity where the speaker has a specific relation to truth through frankness, a certain relationship to his own life through danger, a certain type of relation to himself or other people through criticism (self-criticism or criticism of other people), and a specific relation to moral law through freedom and duty. More precisely, parrhesia is a verbal activity in which a speaker expresses his personal relationship to truth, and risks his life because he recognizes truth-telling as a duty to improve or help other people (as well as himself). In parrhesia, the speaker uses his freedom and chooses frankness instead of persuasion, truth instead of falsehood or silence, the risk of death instead of life and security, criticism instead of flattery, and moral duty instead of self-interest and moral apathy ${ }^{4}$ (Foucault 2001: 19).

4 „Podsumowując powyższe, parezja jest rodzajem aktywności werbalnej, w której mówca nawiązuje szczególną relację z prawdą poprzez szczerość, szczególną relację z własnym życiem poprzez niebezpieczeństwo, szczególną relację z samym sobą i innymi ludźmi poprzez krytykę (samokrytyka lub krytykowanie innych ludzi) oraz szczególną relację z prawem moralnym poprzez wolność i obowiązek. Mówiąc ściślej, parezja jest aktywnością werbalną, w której mówca

122

Fabrica Litterarum Polono-Italica | 2020, nr 1 (2) 
W tym krótkim fragmencie wykładu wygłoszonego przez Foucaulta prawie 40 lat temu na Uniwersytecie w Berkeley trudno znaleźć choćby jedno wyrażenie, które nie pasowałoby do działalności twórczej Saviana. Nawiązując do wiersza lo so Piera Paola Pasoliniego, w którym poeta wyznał „Ja wiem, ale nie mam dowodów. Nie mam nawet poszlak", Saviano pisał w Gomorze...: „Ja wiem i mam dowody. Opowiadam więc o tym. O prawdzie" (Saviano 2008a: 242). Jako Foucaultowski parezjasta pisarz rzeczywiście wybrał szczerość i naraził się na niebezpieczeństwo oraz krytykę innych ludzi. Zamiast kłamstwa czy milczenia wybrał prawdę, zamiast własnego interesu - moralny obowiązek. Choć wiele osób wciąż twierdzi, że było dokładnie na odwrót. Jedno jest pewne, po Gomorze... i kolejnych publikacjach Saviana doszło we Włoszech do wielu zmian zarówno na poziomie świadomości, jak i konkretnych działań.

\section{Rozliczenie i obrachunek}

Karol Franczak we wstępie do książki Kalający własne gniazdo. Artyści i obrachunek z przeszłościq zarysowuje ogólny profil pisarza-„,kalacza”, w który Saviano doskonale się wpisuje. Jako typowy Nestbeschmutzer wyjawia niewygodną prawdę, sytuując się tym samym na pozycji outsidera, a więc decydując się na wyjście z cienia konformizmu i rezygnację z nakazu grupowej lojalności. W przypadku wielu Włochów, którzy uważają Saviana za denuncjatora i zdrajcę własnej kultury, ów nakaz lojalności oznacza oczywiście milczenie.

Franczak zadaje sobie pytanie czy, a jeśli tak, to w jaki sposób wykorzystywana przez „kalaczy” praktyka skandalu przyczynia się do poprawy jakości demokracji i stanu debaty publicznej. Wymienia dwa pojęcia, które określa typami osądzania niechlubnych czynów. Mowa o rozliczeniu (czyli takim rozpatrzeniu winy, którego skutkiem są sankcje prawne) oraz o obrachunku (czyli „krytycznym oglądzie własnego postępowania problematycznego przez samych sprawców lub tych, którzy ponoszą pośrednią odpowiedzialność za popełnione czyny - świadków, biernych obserwatorów, milczącego audytorium" (Franczak 2013: 16)). Jeżeli chodzi o rozliczenie, po Gomorze..., w której autor bezpośrednio wskazał nazwiska, mechanizmy i miejsca działania kamorry, w wyniku oczywistości przedstawionych tam dowodów,

wyraża swój osobisty stosunek do prawdy i ryzykuje życiem, ponieważ mówienie prawdy traktuje jako obowiązek poprawy lub pomocy innym ludziom (a także sobie). W parezji mówca korzysta ze swojej wolności i wybiera szczerość zamiast perswazji, prawdę zamiast kłamstwa lub milczenia, ryzyko śmierci zamiast życia i bezpieczeństwa, krytykę zamiast pochlebstwa oraz moralny obowiązek zamiast własnego interesu i moralnej apatii" [Tłum. - W.K.].

123

Fabrica Litterarum Polono-Italica | 2020, nr 1 (2) 
a także niezwykle wówczas burzliwej debaty publicznej i bardzo dużej międzynarodowej presji społecznej, rozstrzygnięte zostały dwa wielkie i wieloletnie procesy mafijne - Spartacus i Gigant. Na ławie oskarżonych zasiadło aż 70 członków klanu Casalesi, których ostatecznie, w wyrokach drugiej instancji, skazano na dożywocie (po dwóch latach od wydania książki; dla kontrastu: wcześniej czekano aż 12 lat na wyroki pierwszej instancji). Saviano mówi: „Opowiedzenie przeze mnie o tych mechanizmach uniemożliwiło tamtejszej mafii korzystanie z obojętności państwa, jego łagodnej reakcji. Zmusiłem państwo i Włochów, by zdali sobie sprawę z istnienia problemu" (Saviano 2014: 16). Poza tym, również pod naciskiem opinii publicznej włoski rząd wyprowadził patrole wojskowe na opanowane przez kamorrę ulice Casal di Principe.

Jeśli chodzi o obrachunek, nierozsądne byłoby oczekiwanie samokrytyki ze strony organizacji mafijnych - jest ona raczej niemożliwa. Co zaś się tyczy biernych obserwatorów (czyli zwykłego społeczeństwa i polityków), kwestia wydaje się dużo trudniej uchwytna. Saviano twierdzi, że większość czołowych polityków wciąż stosuje strategię „zamiatania pewnych spraw pod dywan”. Z kolei wielu zwykłych obywateli, o czym świadczy chociażby ich stosunek do Saviana, nadal traktuje przestępczość mafijną jako temat tabu. Autor Gomorry... od wielu lat unika bierności i przestrzega przed nią innych. Niewątpliwie zgodziłby się ze stwierdzeniem profesora Philipa Zimbardo, według którego „jedną z najistotniejszych, a najmniej uznawanych przyczyn zła, poza głównymi sprawcami, protagonistami krzywdy, jest milczący chór, który patrzy, lecz nie widzi, który słucha, lecz nie słyszy" (Zimbardo 2017: 117). Nie bądźmy śpiewakami milczącego chóru. Saviano nim nie jest.

\section{Bibliografia}

[b.a.] 2018: Salvini kontra Saviano. Online: https://wiadomosci.onet.pl/swiat/salvini-kontra-saviano/nd9bdrx [dostęp: 20.09.2019].

Benvenuti Giuliana (2018): Il brand "Gomorra". Dal romanzo alla serie tv. Bologna.

BERLUSCONI Silvio (2010): Berlusconi squallido su Saviano. Online: https://www.youtube. com/watch?v=hHMctyL85-M [dostęp: 20.05.2018].

Cepollaro Chiara (2016): Squitieri, minacce e scorta a Saviano: "Sono tutte stronzate", vi spiego il perché... Online: https://www.vesuviolive.it/ultime-notizie/149330-squitieri-minacce-scorta-saviano-tutte-stronzate-vi-spiego-perche [dostęp: 10.10.2019].

D’Avanzo Giuseppe (2008): Io, prigioniero di Gomorra lascio I'Italia per riavere una vita. Online: https://www.repubblica.it/2008/10/sezioni/cronaca/camorra-3/lascio-italia/lascio-italia.html?refresh_ce [dostęp: 14.02.2019].

124

Fabrica Litterarum Polono-Italica | 2020, nr 1 (2) 
DE MAgISTRIS Luigi (2019): https://www.facebook.com/demagistrisluigi/posts/caro-saviano-mi-occupo-di-mafie-criminalit\%C3\%A0-organizzata-e-corruzione-da-circa-25/10154191079742060/ [dostęp: 10.04.2019].

Fanpage.it (2017): In giro per Napoli per capire cosa pensa la città di Roberto Saviano, e se le sue storie sono vere. Online: https://www.youtube.com/watch?v=tMbg0FR21tU [dostęp: 13.10.2019].

Foucault Michel (2001): Fearless speech. Los Angeles.

FranczAK Karol (2013): Kalajq̨cy własne gniazdo. Artyści i obrachunek z przeszłościq. Kraków.

Gambaro Fabio (2007): Roberto Saviano: le pourfendeur de la Camorra. "Le Monde". Online: https://www.lemonde.fr/livres/article/2007/10/18/roberto-saviano-le-pourfendeur-de-la-camorra_968220_3260.html [dostęp: 12.01.2019].

JENKINS Henry (2007): Kultura konwergencji. Zderzenie starych i nowych mediów. Tłum. M. Bernatowicz, M. Filiciak. Warszawa.

Monina Michele (2013): Ricomincio da zero, zero, zero. Roberto Saviano, una biografia. Siena.

Montanaro Giovanna, Silvestrini Francesco (2005): Dalla Mafia allo Stato. I pentiti: analisi e storie. Torino.

SARTRE Jean-Paul (1968): Czym jest literatura. Tłum. J. Lalewicz. Warszawa.

SAviAno Roberto (2008a): Gomorra. Podróż po imperium kamorry. Tłum. A. Pawłowska-Zampino. Warszawa.

SAVIANo Roberto (2008b): Discurso de Roberto Saviano en la Academia Sueca de los Nobel. Online: https://www.youtube.com/watch?v=6SMd284rOnE\&t=121s [dostęp: 25.03.2018].

Saviano Roberto (2010): Piękno i piekło. Teksty z lat 2004-2009. Tłum. A. Pawłowska-Zampino. Warszawa.

SAVIANo Roberto (2014): Chodź ze mnq. Tłum. M. Fafiński. Katowice.

SAVIANO Roberto (2017): Gomorra Channel. Online: https://www.youtube.com/channel/ UCtgllU49ppoBvEgDboD34Pg [dostęp: 14.11.2019].

SAVIANo Roberto (2018): Chłopcy z paranzy. Tłum. A. Pawłowska-Zampino. Katowice.

SAVIANo Roberto (2019a): Drapieżny pocałunek. Tłum. A. Pawłowska-Zampino. Katowice. SAVIANO Roberto (2019b): In mare non esistono taxi. Roma.

SAVIANO Roberto (2019c) Le mafie minacciano. Salvini minaccia. Online: https://www. facebook.com/RobertoSavianoFanpage/videos/le-mafie-minacciano-salvini-minaccia/10155679630941864/ [dostęp: 22.09.2019].

SAVIANO Roberto (2019d): https://www.facebook.com/RobertoSavianoFanpage/videos/robin\%C3\%B9-\%C3\%A8-il-racconto-di-napoli-definirlo-documentario-\%C3\%A8-riduttivo-ne-scrivo-qui-/10153921910711864/ [dostęp: 14.04.2019].

WU MING 1 (2008): NEW ITALIAN EPIC versione 2.0 Memorandum 1993-2008: narrativa, sguardo obliquo, ritorno al futuro. Online: https://www.wumingfoundation. com/italiano/WM1_saggio_sul_new_italian_epic.pdf [dostęp: 13.11.2019].

ZımBardo Philip (2017): Efekt Lucyfera. Tłum. A. Cybulko, J. Kowalczewska, J. Radzicki, M. Zieliński. Warszawa.

125

Fabrica Litterarum Polono-Italica | 2020, nr 1 (2) 


\section{Abstract \\ Roberto Saviano e le conseguenze di insozzare il proprio nido}

Roberto Saviano, scrittore e giornalista investigativo italiano, autore del best-seller Gomorra, da tredici anni vive sotto scorta. Questo è il prezzo che paga per aver rivelato la verità sulle attività della camorra. Saviano è un Nestbeschmutzer, uno scrittore che insozza palesamente il nucleo a cui appartiene, suscitando così emozioni e valutazioni estreme. Lo scopo di questo articolo è quello di esaminare ciò che lo spinge alla costante ricerca della verità. Quali strategie usa per raggiungere il proprio obiettivo? Alla sua lotta senza compromessi come rispondono i politici, gli intellettuali, il "comune" cittadino e l'opinione pubblica internazionale?

Parole chiave: camorra, Nestbeschmutzer, impegno, parresia 